\title{
ANALISIS KOMPETENSI GURU DI SDN GIRIMOYO 2 KABUPATEN MALANG
}

\author{
Erna Yayuk ${ }^{1}$, Arina Restian², Kuncahyono3 \\ 1) Jurusan Pendidikan Guru Sekolah Dasar. Universitas Muhammadiyah Malang \\ 2)Jurusan Pendidikan Guru Sekolah Dasar. Universitas Muhammadiyah Malang \\ 3)Jurusan Pendidikan Guru Sekolah Dasar. Universitas Muhammadiyah Malang
}

\begin{abstract}
Abstrak
The purpose of this research is to know the teacher competence in elementary school of Girimoyo 2 Malang. The research method used in this case is qualitative type, with descriptive approach and done in this step is data analysis taken from interview perspective, this data analysis start from data reduction, data of choice, to conclusion, and data of this instrument taken from interview guide and observation of teachers in the elementary school. The results of this study resulted in 2 findings 1) Competence of teachers after getting educator certificate: able to carry out learning with professional (pedagogic competence, professional, personality, social) and very professional in developing media because of the allowance of teachers. 2) competence of teachers who are getting educator certificate: able with good planning, implementation and evaluation, although there is no teacher allowance, business teacher as much as possible for artificial media.
\end{abstract}

Keywords:

analysis,

teacher competence,

\section{Pendahuluan}

Pendidikan Sekolah Dasar merupakan bagian dari Pendidikan Nasional yang mempunyai peranan sangat penting dalam meningkatkan kualitas sumber daya manusia manusia, dan dapat memberikan bekal kemampuan dasar kepada anak seperti pengetahuan dan keterampilan. Menurut Suharjo (2006:1), pendidikan memainkan peranan penting dalam mengembangkan aspek fisik, intelektual, religius, moral, sosial, emosi, pengetahuan dan pengalaman peserta didik. Pendidikan juga memainkan peranan yang penting dalam pembangunan dan kemajuan negara dan bangsa. Pendidikan formal tidak dapat dilepaskan dari sekolah sebagai institusi yang secara resmi ditugasi untuk menyelenggarakan pendidikan bagi anak bangsa. Sekolah merupakan harapan bagi banyak pihak untuk mampu membentuk generasi bangsa yang handal dan berkualitas, sehingga diperlukan adanya kemantapan sistem dan manajemen pendidikan yang profesional untuk menciptakan sekolah yang efektif, yang mampu melaksanakan misinya secara optimal (Rai, 2005).

Peranan pendidikan dalam memajukan bangsa yaitu tercermin dalam Undang-Undang Nomor 20 Tahun 2003 tentang Sistem Pendidikan Nasional bahwa pendidikan itu berfungsi mengembangkan kemampuan dan membentuk watak serta peradaban bangsa yang bermartabat dalam rangka mencerdaskan kehidupan bangsa, bertujuan untuk berkembangnya potensi peserta didik agar menjadi manusia yang beriman dan bertakwa kepada Tuhan Yang Maha Esa, berakhlak mulia, sehat, berilmu, cakap, kreatif, mandiri dan menjadi warga negara yang demokratis serta bertanggung jawab.

Pendidikan sangat penting untuk meningkatkan kualitas peserta didik. Sehingga dalam proses pendidikan, sosok seorang guru sangat berperanan dalam keberhasilan pendidikan. Guru sebagai ujung tombak pendidikan diharapkan mampu mengelola proses pembelajaran dengan efektif dan menyenangkan, sehingga menghasilkan siswa yang cerdas, terampil, dan berkepribadian yang baik. Adapun komponen yang berperan adalah sekolah, peserta didik, pendidik, dan tenaga kependidikan. Guru adalah pendidik profesional dengan tugas utama mendidik, mengajar, membimbing, mengarahkan, melatih, menilai, dan mengevaluasi peserta didik pada pendidikan usia dini jalur pendidikan formal, pendidikan dasar, dan pendidikan menengah (Damayanthi, 2014). Hal tersebut, mengisyaratkan bahwa setiap guru wajib memiliki kualifikasi akademik dan kompetensi sebagai agen pembelajaran (Ningrum 2016). Oleh karena itu penting adanya peningkatan kualitas guru-guru dalam hal inovasi dan juga 
peningkatan kompetensi Guru, kemampuan personal, keilmuan, teknologi, sosial, dan spiritual yang secara kaffah membentuk kompetensi standar profesi guru, yang menguasai materi, yang meliputi pemahaman karakteristik dan substansi ilmu sumber bahan pembelajaran, pemahaman disiplin ilmu yang bersangkutan dalam konteks yang lebih luas, penggunaan metodolgi ilmu yang bersangkutan untuk memverifikasi dan memantapkan pemahaman konsep yang dipelajari, serta pemahaman manajemen pembelajaran. Pemahaman terhadap peserta didik meliputi karakteristik, tahap-tahap perkembangan dalam berbagai aspek dan penerapannya (koqnitif, afektif, dan psikomotor) dalam mengoptimalkan perkembangan dan pembelajaran. Menurut Kristiantari (2014), guru tidak boleh berubah di dalam fungsinya sebagai transformer ilmu dan pamong bagi para siswa. Selain itu juga contoh di dalam kehidupan masyarakat. Sebagai transformer ilmu pengetahuan maka di dalam dirinya harus ada mindset untuk melakukan yang terbaik bagi profesinya sebagai guru dan sebagai pamong maka dia akan membimbing para siswanya di dalam proses pencarian kebenaran yang berbasis pada ilmu pengetahuan. Demikian pula guru adalah contoh bagi para siswa di dalam karakter dan tindakan. Di era global persaingan semakin keras dan ketat yang disertai dengan munculnya permasalahan yang semakin kompleks, khususnya dalam pembelajaran menuntut profesionalisme guru yang semakin meningkat. Untuk menyiasati kompetisi yang semakin ketat dan kompleksnya permasalahan mengharuskan seorang guru mau, mampu, dan berani berubah (Mustika, 2016).

Pembelajaran ini bersifat mendidik, yang terdiri atas pemahaman konsep dasar proses pendidikan dan pembelajaran bidang studi yang bersangkutan, serta penerapannya dalam pelaksanaan dan pengembangan pembelajaran. Pengembangan kepribadian profesionalisme, yang mencakup pengembangan intuisi keagamaan yang berkepribadian, sikap dan kemampuan mengaktualisasikan diri, serta sikap dan kemampuan mengembangkan profesionalisme kependidikan Undang-Undang Republik Indonesia No. 20 tahun 2003 tentang Sisdiknas, pasal 9 ayat (2), menyatakan bahwa pendidik merupakan tenaga profesional yang bertugas merencanakan dan melaksanakan proses pembelajaran, menilai hasil pembelajaran, melakukan pembimbingan dan pelatihan serta melakukan penelitian dan pengabdian kepada masyarakat, terutama bagi pendidik pada perguruan tinggi. Guru professional dibuktikan dengan sertifikat guru professional yang sering disebut dengan sertifikasi guru. Guru bersertifikasi adalah guru yang professional dan memenuhi kompetensi dasar guru. Guru bersertifikasi mendapatkan penghargaan berupa tunjangan ( Murdadi, 2015). Adanya sertifikasi pendidik, juga diharapkan kompetensi guru sebagai pengajar akan meningkat sesuai dengan standar yang telah ditetapkan .Undang-undang guru dan dosen menyatakan dengan jelas bahwa, sertifikasi sebagai bagian dari peningkatan mutu guru dan peningkatan kesejahteraannya. Oleh karena itu, lewat sertifikasi ini diharapkan guru menjadi pendidik yang professional.

Hal ini didukung dengan kebijakan Undang-Undang No. 14 Tahun 2005 tentang Guru dan Dosen menyatakan bahwa standar prestasi kerja guru dalam melaksanakan tugas keprofesionalannya, guru berkewajiban merencanakan pembelajaran, melaksanakan proses pembelajaran yang bermutu serta menilai dan mengevaluasi hasil pembelajaran. Tugas pokok guru tersebut yang diwujudkan dalam kegiatan belajar mengajar merupakan bentuk kinerja guru. Oleh karena itu peneliti, mengangkat konsep peningkatan guru-guru dalam meningkatkan kualitas SDM guru-guru dalam rangka meningkatkan kinerja guru, dengan melihat peningkatan kompetensinya yaitu kompetensi pedagogik, kompetensi profesional, kompetensi kepribadian, dan kompetensi sosial, karena SDM guru- guru di SDN Girimoyo 2 Malang sangat memerlukan penyegaran berupa penelitian dari akademisi.

Berdasarkan hasil observasi awal diketahui bahwa guru-guru yang ada di Sekolah Dasar SDN Girimiyo 2 Malang adalah guru-guru yang berjumlah sedikit dan sudah berusia 50 tahun ke atas. Adapun jumlah guru keseluruhan yang tetap tersebut adalah 8 orang dan yang tidak tetap ada 4 guru. Di sekolah tersebut terdapat fasilitas penunjang guru dan siswa masih kurang, dilihat dari beberapa kelas yang kurang kondusif penyebab dari minimnya prestasi yang diraih oleh siswa. Melihat kondisi tersebut perlu diperhatikan karena para guru tersebut dalam mengajar kurang maksimal dalam proses pembelajaran karena terbatasnya tenaga pendidik terutama bagi SDN Girimoyo 2 Malang diatasi dengan cara merekrut guru kontrak atau guru honorer.

Lebih lanjut hasil terdapat hasil refleksi dengan guru dan kepala sekolah memaparkan bahwa (1) kurikulum yang digunakan di Sekolah Sekolah Dasar SDN Girimoyo 2 Malang masih menggunakan kurikulum KTSP, (2) sebagian besar guru yang mengajar tanpa menggunakan alat bantu atau media. Hal ini jika dibiarkan akan berdampak pada aktivitas dan hasil belajar siswa. Berdasarkan paparan tersebut untuk itulah perlu dikaji secara mendalam bagaimanakah kompetensi guru SD dalam mengelola pembelajaran di sekolah dasar. 


\section{Metode Penelitian}

Penelitian ini mengambil lokasi di SDN Girimoyo 2 Kabupaten Malang. Penentuan subjek penelitian dilakukan secara purposif berdasarkan hasil studi dokumentasi, observasi, dan monitoring evaluasi yang meliputi yang meliputi: kepala sekolah, guru sasaran, dan guru sebagai teman sejawat. Secara terperinci subjek penelitian untuk masing-masing sekolah terdiri dari: kepala sekolah, tiga guru sasaran, dan dua guru teman sejawat.

Instrumen yang digunakan dalam penelitian ini adalah: (1) peneliti, sebagai instrumen utama penelitian; (2) pedoman wawancara (interview guide), berupa pertanyaan terbuka yang memungkinkan setiap pertanyaan berkembang ke arah yang lebih spesifik; (3) catatan lapangan (field notes), digunakan untuk mencatat apa yang didengar, dilihat, dialami dan dipikirkan dalam rangka pengumpulan data di lapangan; (4) alat perekam (recorder) sebagai alat bantu merekam hasil wawancara. Pengumpulan data dilakukan dengan melakukan observasi, indept interview (wawancara mendalam), Focus Group Discussion (FGD) dan pemanfaatan dokumen.

Teknik analisis data menggunakan triangulasi teknik, hal ini dilakukan untuk menguji kredibilitas data dengan cara mengecek data kepada sumber yang sama dengan teknik yang berbeda. Adapun triangulasi teknik ditempuh melalui langkah-langkah yaitu peneliti mengunakan observasi langsung di SDN Girimoyo 2 untuk melihat kompetensi guru langsung dan mengisi angket Pedoman FGD, wawancara langsung dengan guru-guru kelas maupun yang guru bidang untuk melihat kompetensi "Pedagogik, Profesional, kepribadian, dan sosial", serta dokumentasi langsung saat wawancara dengan guru- guru sebagai data informan di SDN Girimoyo 2.

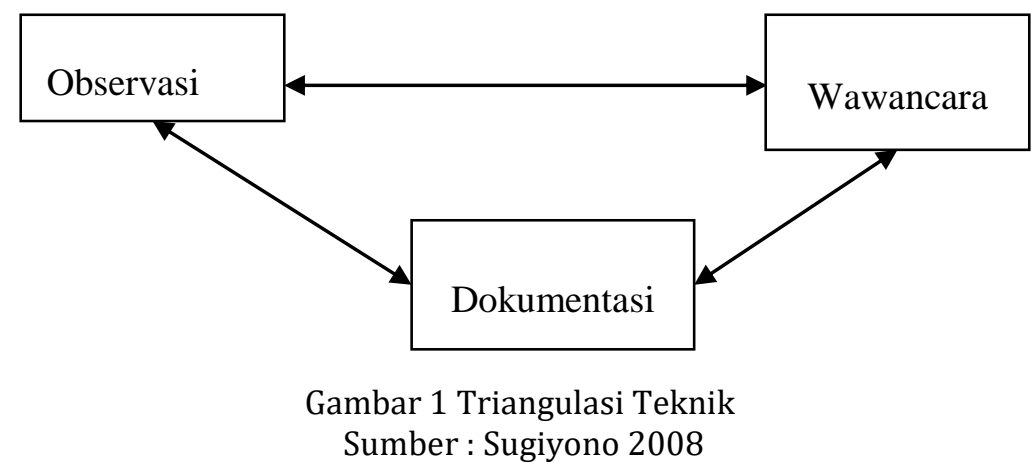

\section{Hasil Dan Pembahasan}

Berdasarkan hasil wawancara, dan kegiatan FGD yang sudah diakukan ditemukan implementasi Kompetensi guru di SDN Girimoyo 2 Kabupaten Malang. Adapun paparan perbedaan kompetensi guru di SDN Girimoyo 2 Kabupaten Malang menurut data lapangan dapat dilihat tabel sebagai berikut:

Tabel 1 Perbedaan Kompetensi guru di SDN Girimoyo 2 Malang

\begin{tabular}{|c|c|c|}
\hline No & $\begin{array}{l}\text { Kompetensi guru setelah sertifikasi di SDN } \\
\text { Girimoyo } 2 \text { Malang }\end{array}$ & $\begin{array}{c}\text { Kompetensi guru sebelum } \\
\text { disertifikasi di SDN Girimoyo } 2 \\
\text { Malang }\end{array}$ \\
\hline 1. & $\begin{array}{l}\text { Berjumlah } 2 \text { guru (1 Kepala sekolah dan } 1 \\
\text { guru) }\end{array}$ & Berjumlah 5 guru (5 guru kelas) \\
\hline 2. & $\begin{array}{l}\text { Perencanaan } \\
\text { Mampu merencanakan RPP dengan Baik }\end{array}$ & $\begin{array}{l}\text { Perencanaan } \\
\text { Mampu merencanakan RPP dengan } \\
\text { Baik }\end{array}$ \\
\hline 3. & $\begin{array}{l}\text { a) Pelaksanaan Kompetensi Pedagogik } \\
\text { (Sudah baik dalam melakukan } \\
\text { perencanaan dengan baik, karena } \\
\text { adanya tunjangan sertifikasi, sehingga } \\
\text { dari segi menyampaikan media sangat } \\
\text { maksimal) } \\
\text { b) Kompetensi Profesional (sudah sangat } \\
\text { pengalaman dilihat dari usia dan }\end{array}$ & $\begin{array}{l}\text { a) Pelaksanaan Kompetensi } \\
\text { Pedagogik (Perlu adanya } \\
\text { bimbingan untuk mengembangkan } \\
\text { materi dengan baik) } \\
\text { b) Kompetensi Profesional (Perlu } \\
\text { adanya pendampingan } \\
\text { professional seperti pelatihan, } \\
\text { dsb) }\end{array}$ \\
\hline
\end{tabular}




\begin{tabular}{|c|c|c|}
\hline & $\begin{array}{l}\text { pengalaman mengikuti pelatihan dan } \\
\text { pengabdian masyarakat) } \\
\text { c) Kompetensi kepribadian (Sudah } \\
\text { otomatis sangat berkrepribadian yang } \\
\text { baik) } \\
\text { d) Kompetensi sosial (Sudah baik karena } \\
\text { kebijakan sekolah adanya komunikasi } \\
\text { dengan siswa dan guru secara baik) }\end{array}$ & $\begin{array}{l}\text { c) Kompetensi kepribadian (Sudah } \\
\text { baik dilihat dengan kepribadian } \\
\text { sosok Pendidik) } \\
\text { d) Kompetensi social (Sudah baik, } \\
\text { karena adanya kerjasama siswa } \\
\text { dengan guru) }\end{array}$ \\
\hline 4. & $\begin{array}{l}\text { Evaluasi } \\
\text { Peningkatan komitmen guru setelah } \\
\text { mendapatkan serifikasi pendidik } \\
\text { Peningkatan kinerja guru setelah } \\
\text { mendapatkan sertifikat pendidik } \\
\text { Perubahan perilaku guru setelah } \\
\text { mendapatkan sertifikat pendidik } \\
\text { Dampak setelah mendapatkan sertifikasi } \\
\text { guru }\end{array}$ & $\begin{array}{l}\text { Evaluasi } \\
\text { Peningkatan komitmen guru setelah } \\
\text { mendapatkan serifikasi pendidik } \\
\text { Peningkatan kinerja guru setelah } \\
\text { mendapatkan sertifikat pendidik } \\
\text { Perubahan perilaku guru setelah } \\
\text { mendapatkan sertifikat pendidik } \\
\text { Dampak setelah mendapatkan } \\
\text { sertifikasi sebelum sertifikasi guru } \\
\text { guru }\end{array}$ \\
\hline
\end{tabular}

Berdasarkan paparan tabel di atas dapat dideskripsikan sebagai berikut:

1) Kompetensi guru setelah mendapatkan sertifikat pendidik

SDN Girimoyo 2 Malang sudah melalui peningkatan professional sejak tahun 2000, hal ini diperkuat Pasca disahkannya UU No. 14 Tahun 2005 tentang guru dan dosen, profesi guru dan dosen kembali menjadi bahan pertimbangan oleh banyak pihak khususnya bagi mereka yang berkecimpung dalam dunia pendidikan. Mengapa tidak kehadiran undang- undang tersebut manambah wacana baru akan dimantapkannya hak- hak dan kewajiban bagi guru dan dosen. Diantara hak yang paling ditunggu selama ini adalah adanya upaya perbaikan kesejahteraan bagi guru dan dosen, salah satu upaya yang sementara dilaksanakan saat ini dalam rangka implementasi UUGD adalah pelaksanaan sertifikasi guru dalam jabatan sebagaimana telah diatur dalam peraturan Menteri Pendidikan Nasional RI Nomor 18 Tahun 2007.

Banyak kalangan yang pesimis dengan adanya sertifikasi guru dan dosen ini, khususnya bagi mereka yang sampai saat ini belum memiliki kualifikasi akademik (S1) atau Diploma empat (D4) namun tak sedikit yang merasa gembira dan berbahagia terutama bagi mereka yang sudah dinyatakan lulus karena sudah barang tentu setelah dinyatakan lulus, sudah ada jaminan bagi mereka bahwa pemerintah segera akan membayar tunjangan profesi tersebut, sebuah harapan sekaligus tantangan menuju guru profesional. Berbagai upaya yang telah dilakukan pemerintah dalam meningkatkan mutu pendidikan, antara lain menata sarana dan prasarana, mengutak atik kurikulum, meningkatkan kualitas guru melalui peningkatan kualifikasi pendidikan guru, memberikan berbagai diklat atau pelatihan sampai pada meningkatkan tunjangan profesi guru dalam arti meningkatkan kesejahteraan guru. (Contoh Kasus DKI Jakarta mulai tahun 2006 setiap guru menerima tunjangan kesejahteraan sebesar dua juta rupiah perbulan selain gaji dan tunjangan lainnya: Suara Karya, 13 Desember 2005).

Fenomena ini menunjukkan bahwa dari sisi kesejahteraan sudah ada upaya konkrit yang dilakukan oleh pemerintah untuk memenuhi hak guru, apalagi saat ini sertifikasi guru sudah mulai dilaksanakan dalam rangka pemberian tunjangan profesi sebagaimana diatur dalam Undang- Undang Guru dan Dosen, persoalannya adalah apakah dengan pemberian tunjangan profesi akan melahirkan guru profesional jawabannya terpulang kepada setiap pribadi guru, dan sangat nampak adanya pengaruh sertifikasi, akan memaksimalkan setiap penggunaan perencanaan, pelaksanaan yang baik dan professional serta evaluasi dengan benar, karena didukung dengan pengalaman yang sudah matang dari segi kesiapan Profesional di SDN Girimoyo 2 Malang.

2) Kompetensi guru yang belum mendapatkan sertifikat pendidik

Dengan adanya pendataan melalui FGD di SDN Girimoyo 2 Malang perlu adanya pendampingan menuju pendidik professional, Sesungguhnya paradigma baru pendidikan nasional, telah menempatkan pendidik sebagai tenaga profesionalyang bertugas merencanakan dan melaksanakan proses pembelajaran, menilai hasil pembelajaran, melakukan pembimbingan dan pelatihan, serta melakukan penelitian dan pengabdian masyarakat. Dalam ketentuan umum UUGD (pasal1) pengertian professional diberi rumusan: "Profesional adalah kegiatan atau yang dilakukan seseorang dan menjadi sumber penghasilan kehidupan yang memerlukan keahlian, kemahiran atau kecakapan yang memenuhi standar mutu atau norma tertentu, serta memerlukan pendidikan profesi". 
Selanjutnya pasal 7 ayat 1 UUGD ditetapkan dengan jelas sembilan prinsip professional yaitu guru dan dosen: (a) memiliki bakat, minat dan panggilan jiwa dan idealisme, (b) memiliki komitmen untuk meningkatkan mutu pendidikan, keimanan, ketaqwaan, dan akhlak mulia, (c) memiliki kualifikasi akademik dan latar belakang pendidikan social dengan bidang tugas, (d) memiliki kompetensi yang diperlukan sesuai dengan bidang tugas, (e) memiliki tanggung jawaba atas pelaksanaan tugas keprofesionalan, (f) memperoleh penghasilan yang ditentukan sesuai dengan prestasi kerja, (g) memiliki kesempatan untuk mengembangkan keprofesionalan secara berkelanjutan dengan bvelajar sepanjang hayat, (h) memiliki jaminan perlindungan hokum dalam melaksanakan tugas keprofesionalannya dan khusus bagi guru harus, (i) memiliki organisasi profesi yang mempunyai kewenangan mengatur hal- hal berkaitan dengan tugas keprofesionalan guru.

Pemberdayaan profesi guru atau pemberdayaan profesi dosen dilaksanakan melalui pengembangan diri yang dilakukan secara demokratis, berkeadilan, tidak diskriminatif dan berkelanjutan dengan menjunjung tinggi hak asasi manusia, nilai keagamaan, nilai cultural, kemajemukan bangsa dan kode etik organisasi profesi (pasal 7 ayat 2 UUGD).Selain itu dalam pasal 1 ayat 1 butir 1 UUGD ditetapkan bahwa guru adalah pendidik profesional dengan tugas utama mendidik, mengajar, membimbing, mengarahkan, melatih, menilai dan mengevaluasi peserta didik pada jalur pendidikan formal, pendidikan dasar dan pendidikan menengah termasuk pendidikan usia dini. Kedudukan guru sebagai tenaga professional diatur lebih rinci pada pasal 2 ayat 1 UUGD disebutkan bahwa guru mempunyai kedudukan sebagai tenaga profesional pada jenjang pendidikan dasar, pendidikan menengah, dan pendidikan anak usia dini pada jalur pendidikan formal yang diangkat sesuai dengan peraturan perundang- undangan. Pengakuan kedudukan guru sebagai tenaga profesional dibuktikan dengan sertifikat pendidik (pasal 2 ayat 2 UUGD).

Pengakuan kedudukan guru sebagai tenaga profesional yang dibuktikan dengan sertifikat pendidik berfungsi untuk meningkatkan martabat dan peran guru sebagai agen pembelajaran dalam meningkatkan mutu pendidikan (pasal 4 UUGD) selanjutnya kedudukan guru sebagai tenaga professional bertujuan untuk melaksanakan system pendidikan nasional dan mewujudkan tujuan pendidikan nasional yaitu berkembangnya potensi peserta didik agar menjadi manusia yang beriman dan bertaqwa kepada Tuhan Yang Maha Esa, berakhlak mulia, sehat, berilmu, cakap, kreatif, mandiri, serta menjadi warga Negara yang demokratis dan bertanggung jawab (pasal 6 UUGD).

Patut disadari bahwa kedudukan guru sebagai tenaga profesional dimaksudkan agar guru mempunyai kompetensi ilmu, teknis dan moral dalam menjalankan tugasnya secara bertanggung jawab dengan jaminan kesejahteraan yang memadai untuk memenuhi hak warga Negara memperoleh pendidikan yang bermutu (pasal 5 UU Sisdiknas) bahkan lebih jauh dari itu untuk mencerdaskan kehidupan bangsa, dengan mecapai tujuan pendidikan nasional (Prof. Anwar Arifin, eksistensi dan implementasi UUGD).

Perlu ditegaskan bahwa sertifikat merupakan sarana atau instrumen meningkatkan kualitas kompetensi gurusupaya menjadi guru yang profesional, untuk sertifikasi guru bukan tujuan melainkan sarana untuk mencapai tujuan yaitu menciptakan guru yang berkualitas, oleh karena itu perlu diwaspadai adanya kecenderungan sebagai orang yang melihat bahwa sertifikasi guru adalah tujuan, sebab kalau ini yang terjadi maka kualitas guru yang diharapkan tidak akan tercapai (Fasli Jala, Sertifikasi Guru Mewujudkan Pendidikan yang Bermutu).

Keberadaan guru yang berkualitas merupakan syarat mutlak hadirnya sistem dan praktik pendidikan yang berkualitas, hampir semua bangsa didunia ini selalu mengembangkan kebijakan yang mendorong keberadaan guru yang berkualitas. Beberapa Negara seperti Singapura, Korea Selatan, Jepang dan USA berupaya meningkatkan kualitas guru dengan mengembangkan kebijakan yang langsung mempengaruhi mutu guru dengan melaksanakan sertifikasi guru. Guru yang sudah ada harus mengikuti uji kompetensi untuk mendapatkan sertifikasi profesi guru.

Undang-Undang Guru dan Dosen (UUGD) telah ditetapkan dan sudah menjadi suatu kebijakan untuk mewujudkan guru yang profesional dan menetapkan kualifikasi dan sertifikasi sebagai bagian penting dalam menentukan kualitas dan kepentingan guru. Upaya sungguh- sungguh perlu dilaksanakan untuk mewujudkan guru yang profesional, sejahtera dan memiliki kompetensi. Hal ini merupakan syarat mutlak untuk menciptakan sistem dan praktek pendidikan yang berkualitas sebagai prasyarat untuk mewujudkan kemakmuruan dan kemajuan bangsa Indonesia.

Hal ini menjadi pedoman utama dilihat dari grafik PLPG 2017 sebagai berikut: 


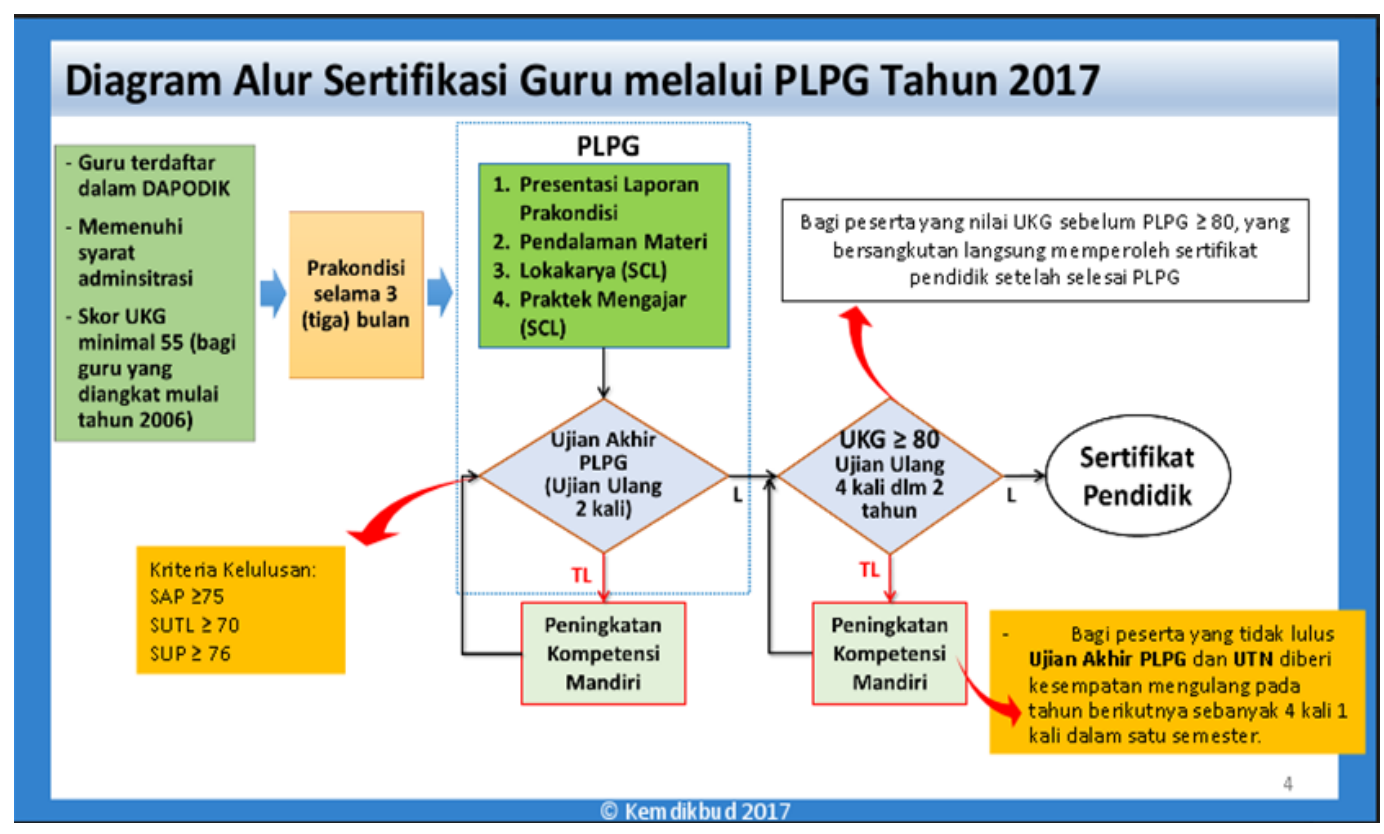

Gambar 2 Diagram Alur Sertifikasi Guru

PLPG singkatan dari Pendidikan dan Pelatihan Profesi Guru. PLPG ini diadakan bagi guru yang sudah memenuhi syarat untuk menerima tunjangan profesi (sertifikasi) agar dapat meningkatkan kompetensi dan profesionalisme guru sebagai pengganti diharapkan. PLPG sendiri hadir sebagai ganti dari porptofolio yang dinilai kurang maksimal dalam menjaring guru agar lulus sertifikasi.

Adapun Materi PLPG pada dasarnya semua materi yang diberikan sangat bermanfaat bagi peserta, namun ada satu materi yang berbeda dan merupakan teknik yang baru pada pelaksanaan pembelajaran di kelas yaitu Model pembelajaran PAKEM, dan Pemanfaatan Media Belajar, serta Pembuatan RPP yang baik dan benar. Ada banyak model atau strategi yang dikembangkan oleh para ahli dalam usaha untuk mengoptimalkan hasil belajar siswa, diantaranya pembelajaran Kontekstual, Model Pembelajaran Kooperatif, Model Pembelajaran Quantum, Model Pembelajaran Terpadu, Pembelajaran Berbasis Masalah (PBL). Materi dalam PLPG yang dipelajari antara lain Pengertian Media Pembelajaran, berbagai macam bentuk media pembelajaran seperti; media Visual, Media Audio, Media Audio Visual, Multimedia, pengembangan media sederhana, cara pemilihan media dan penggunaaan media dalam pembelajaran. Yang lebih khusus lagi bahwa materi PLPG disesuaikan dengan pelajaran yang diampuh. Itupun masih tergantung dari narasumbernya karena setiap narasumber menyampaikan materi dari sudut pandang yang bermacam-macam.

Hasil penelitian ini didukung oleh hasil penelitian yang dilakukan oleh Masdiantoro (2016), yang menyatakan bahwa secara simultan kompetensi guru (kompetensi pedagogik, kompetensi kepribadian, kompetensi sosial, dan kompetensi profesional) berpengaruh signifikan terhadap kinerja guru. Selanjutnya, penelitian lain yang mendukung hasil penelitian ini dilakukan oleh Husni (2014), yang menyatakan bahwa kompentensi (kompetensi pedagogik, kompetensi kepribadian, kompetensi sosial, dan kompetensi profesional) berpengaruh signifikan terhadap kinerja guru. Hasil penelitian menunjukkan bahwa terdapat pengaruh yang signifikan antara kompetensi guru (kompetensi pedagogik, kompetensi profesional, kompetensi sosial, dan kompetensi kepribadian) terhadap kinerja guru, yang ditunjukkan dengan nilai probabilitas uji $\mathrm{F}$ sebesar 0,000 lebih kecil dari 0,05. Berdasarkan hasil penelitian, dapat diambil suatu kesimpulan bahwa terdapat pengaruh yang signifikan anatara kompetensi guru (kompetensi pedagogik, kompetensi kepribadian, kompetensi sosial, dan kompetensi profesional) terhadap kinerja guru (Ningrum,2016).

\section{Simpulan dan Saran}

Kompetensi guru setelah mendapatkan sertifikat pendidik: mampu merencanakan proses pembelajaran dengan professional (1) Kompetensi pedagogic, Perencanaan guru dalam 1) Perencanaan RPP, Silabus. 2) Pelaksanaan guru mulai dari mempersiapkan media, metode, materi dengan sebaikbaiknya. hingga 3) evaluasinya berupa a) Tes tertulis b) Observasi c) Tes Kinerja d) Penugasan e) Tes Lisan f) Penilaian Portofolio g) Jurnal h) Inventori i) Penilaian Diri j) Penilaian Antar Teman. (2) 
Kompetensi professional, (3) Kompetensi kepribadian,(4) Kompetensi sosial) dan sangat professional dalam mengembangkan media karena adanya tunjangan guru.

Kompetensi guru yang belum mendapatkan sertifikat pendidik : mampu merencanakaPerencanaan guru dalam 1) Perencanaan RPP, Silabus. 2) Pelaksanaan guru mulai dari mempersiapkan media, metode, materi, pelaksanaan dan evaluasi, walaupun belum adanya tunjangan guru, guru berusaha semaksimal mungkin untuk membuat media, namun perlu adanya pendampingan khusus untuk meningkatkan pendidik Profesional.

Diharapkan Guru di SD dapat tetap mengajar dengan professional dengan sebaik mungkin, dan tidak ada bedanya antara yang menerima sertifikasi maupun yang belum, untuk meningkatkan kualitas pendidik dalam mengajar secara professional walaupun secara administrative masuk kategori kompetensi yang sudah di siapkan pemerintah dari segi kurikulum dan menuju 4 kompetensi. Perlu adanya kebijakan dari Kepala Sekolah untuk penerapan Penilaian yang efektif untuk meningkatkan kualitas gaya mengajar secara keseluruhan untuk tetap menyampaikan dan menuju pendidik professional.

\section{Daftar Pustaka}

Abdillah, N., dkk. 2014. Opini Stakeholder Dampak Kabijakan Sertifikasi Guru Terhadap Profesionalisme Guru di Kab. Gresik. Jurnal Kependidikan Islam, volume 4 (2): 334-368

Abubakar, A., 2015. Dampak Sertifikasi Guru Terhadap Kualitas Pendidikan pada Madrasah Aliyah di Kota Kendari. Jurnal “Al-Qalam" Volume 21 (1): 117-128

Arifin anwar, 2006. Eksistensi dan Implementasi UUGD

Borg, W.R. \& Gall, M.D. 2003. Educational Research, An Introduction. Fourth Edition. New York: Longman

Budiningsih, A. 2004. Belajar dan Pembelajaran. Yogjakarta: Rineka Cipta Jakarta : BPP

Damayanthi, I Gst. Ayu Eka, Anak Agung Gede Agung, Ni Ketut Suarni. 2014. Analisis Kompetensi Pedagogik Dan Kompetensi Profesional Ditinjau Dari Output Institusi Pada Para Guru SMP Negeri Di Kota Denpasar. E-journal Pacsa Undiksha tersedia di. http;//pasca.undiksha.ac.id/ejournal/index.php/jurnal_ap/article/download/

Hasanah, N., 2010. Sertifikasi Sebagai Upaya Peningkatan Profesionalisme Guru. Salatiga: Sekolah Tinggi Agama Islam Negeri (STAIN).

Husni, Yusratul. 2014. Pengaruh Kompetensi Terhadap Kinerja Guru (Studi Kasus Sltp Di Kota Sawahlunto). Tesis. Program Studi Magister Perencanaan Pembangunan Fakultas Ekonomi Universitas Andalas.

Koswara, D., dkk., 2009. Studi Dampak Program Sertifikasi Guru terhadap Peningkatan Profesionalisme dan Mutu di Jawa Barat. Artikel hasil penilitian: Hibah Fundamental Tahun.

Kunandar, 2007. Guru Profesional Implementasi Kurikulum Tingkat Satuan Pembelajran (KTSP) dan Sukses dalam Sertifiaksi Guru. Jakarta: PT. Rajawali Pers.

Kementerian Pendidikan dan Kebudayaan. 2013. Standar Nasional Pendidikan.

Kristiantari, Mg. Rini2014. Analisis Kesiapan Guru Sekolah Dasar Dalam Mengimplementasikan Pembelajaran Tematik Integratif Menyongsong Kurikulum 2013. Jurnal Pendidikan Indonesia Universitas Pendidikan Ganesha, Vol. 3, No. 2.

Masdiantoro. 2016. Pengaruh Kompetensi Profesional, Kepemimpinan Kepala Sekolah, dan Kepuasan Kerja Terhadap Kinerja Guru SMP di Kecamatan Kasihan Bantul Yogyakarta Tahun Pelajaran 2015/2016. Tesis. Program Studi Pendidikan Ilmu Pengetahuan Sosial Program Pascasarjana Universitas Pgri Yogyakarta

Moleong, L. J., 2010. Metodologi Penelitian Kualitatif. Bandung: Remaja Rosdakarya.

Muhajir, N., 1996. Metodologi Penelitian Kualitatif. Yogyakarta: Rake Sarasin.

Mulyasa, E. 2008. Standar Kompetensi dan Sertifikasi Guru. Bandung: PT. Remaja Rosda Karya. 
Murdadi, Imanuel Sri dan EntriSulistari. 2015. Dampak sertifikasi guru dalam peningkatan kompetensi Profesional dikalangan guru SMK Pelita Salatiga. Prosiding Seminar Nasional.

Mustika, Pande Wayan, I Made Sutajaya. 2016. Ergonomi Dalam Pembelajaran Menunjang Profesionalisme Guru Di Era Global. Jurnal Pendidikan Indonesia Universitas Pendidikan Ganesha Volume 5 Nomor 1.

Ningrum, Komang Septia Cahya2016. Pengaruh Kompetensi Guru Terhadap Kinerja Guru Smp Negeri 6 Singaraja. Jurnal Program Studi Pendidikan Ekonomi (JPPE) Volume: 7 Nomor: 2

Rai, I Wayan. 2005. Kompetensi Guru Sosiologi Sekolah Menengah Atas Negeri Di Kabupaten Buleleng. Jurnal Pendidikan dan Pengajaran Universitas Pendidikan Ganesha.

Sugiyono. 2013. Metode Penelitian Pendidikan. Bandung: Alfabeta.

Undang-Undang Republik Indonesia, Nomor: 20 Tahun 2003 tentang Sisdiknas (Sistem Pendidikan Nasional), Penerbit Fokusmedia Bandung.

Undang-Undang Republik Indonesia, Nomor: 18 Tahun 2007 tentang sertifikasi guru dalam jabatan (Sistem Pendidikan Nasional), Penerbit Fokusmedia Bandung.Fasli jalal, 2007. Sertifikasi Guru Untuk Mewujudkan Pendidikan yang Bermutu 